\title{
PERTAMBANGAN DAN KEMISKINAN STRUKTURAL MASYARAKAT PULAU KECIL (Studi Kasus Masyarakat Desa Sarakaman, Pulau Sebuku, Kotabaru, Kalimantan Selatan)
}

\author{
Mining and Structural Poverty of Islet Community \\ (A Case Study of Community Sarakaman, Kotabaru, South Kalimantan)
}

\author{
Lukman Hakim*), Rilus A. Kinseng, dan Ivanovich Agusta
}

Departemen Sains Komunikasi dan Pengembangan Masyarakat, Fakultas Ekologi Manusia, IPB

*Email: lukmanhakim1989@yahoo.co.id

\begin{abstract}
This research was conducted in the village of Sarakaman, District of Sebuku Island, Kotabaru, South Kalimantan. There are two mining industry corporations in Sebuku Island. They are PT Bahari Cakrawala Sebuku (PT BCS) and PT Sebuku Iron Lateritic Ores (PT SILO). PT BCS was established since 1997 and PT SILO was established 2004. In 2010 PT BCS and PT SILO expand the exploitation area in Sarakaman. Sarakaman community was the subject of this research. The purpose of this research were: (1) To analyze the process of mining industrialization in Sebuku Island and (2) To analyze the dynamics of the community poverty as the impact of mining industrialization in Sebuku Island. The data were collected through participant observation, indepth interviews, focus group discussions, the study of literature/documents and participation in community activities. This research concluded: (1) permits of mining industry corporations given by local government without local communities agreement, (2) compensation of land acquisition and residential communities conducted by mining industry corporations was fairly large, but not comparable to the community socioeconomic sustainability, (3) Acquisition of land and residential communities by mining industry corporations reduce the accessibility of resources agrarian society, (4) in limited of agrarian resource access, the community survive with their livelihood strategies, (5) environmental damage as the effect of the mining industry activities make difficult the activity and subsistence of communities.
\end{abstract}

Key words: accessibility, islet community, mining industrialization, structural poverty

\section{ABSTRAK}

Penelitian ini dilakukan di Desa Sarakaman, Kecamatan Pulau Sebuku, Kotabaru, Kalimantan Selatan. Ada dua perusahaan industri pertambangan di Pulau Sebuku. Mereka adalah PT Bahari Cakrawala Sebuku(BCS PT) dan PT Sebuku Iron Lateritic Ores (SILO PT). PT BCS didirikan sejak tahun 1997 dan PT SILO didirikan tahun 2004. Pada tahun 2010 PT BCS dan PT SILO memperluas wilayah eksploitasi di Sarakaman. Masyarakat Sarakaman adalah subjek penelitian ini. Tujuan dari penelitian ini adalah: (1) Untuk menganalisis proses industrialisasi pertambangan di Pulau Sebuku dan (2) Untuk menganalisis dinamika kemiskinan masyarakat sebagai dampak industrialisasi pertambangan di Pulau Sebuku. Data dikumpulkan melalui observasi partisipan, wawancara mendalam, diskusi kelompok, studi literatur / dokumen dan partisipasi dalam kegiatan masyarakat. Penelitian ini menyimpulkan: (1) izin dari perusahaan-perusahaan industri pertambangan yang diberikan oleh pemerintah daerah tanpa persetujuan masyarakat lokal, (2) kompensasi pembebasan lahan dan pemukiman masyarakat yang dilakukan oleh perusahaan-perusahaan industri pertambangan cukup besar, tapi tidak sebanding dengan keberlanjutan sosial ekonomi masyarakat , (3) Akuisisi lahan dan pemukiman masyarakat oleh perusahaan industri pertambangan mengurangi aksesibilitas sumber daya masyarakat agraris, (4) pada keterbatasan akses sumber daya agraria, masyarakat bertahan dengan strategi mata pencaharian mereka, (5) kerusakan lingkungan sebagai dampak dari kegiatan industri pertambangan membuat sulit aktivitas dan penghidupan masyarakat.

Kata kunci: aksesibilitas, industrialisasi pertambangan, kemiskinan struktural, masyarakat pulau

\section{PENDAHULUAN}

\section{Latar Belakang}

Pulau Sebuku memiliki potensi tambang yang besar, dengan kandungan batu bara dan bijih besi di dalamnya. Dampak dari kebijakan daerah (SK Bupati Kotabaru No. 142/1997; SK Bupati Kotabaru No 545/56.1/KP/D.PE; SK Bupati Kotabaru No 545/11.1/KP/D.PE dan SK Bupati Kotabaru No 545/07/IUPOP/D.PE/2010) dan aturan perundang- undangan (Peraturan Menteri Kelautan dan Perikanan RI Nomor Per. 20/MEN/2008 tentang pemanfaatan pulaupulau kecil dan perairan di sekitarnya, dijelaskan pada pasal 3 ayat (1) mengakibatkan Pulau Kecil Sebuku yang sebenarnya begitu rentan untuk dilakukan eksploitasi tambang menjadi arena dalam mengeruk keuntungan oleh kapitalis besar. Masuknya perusahan tambang untuk pertama kali di Pulau Sebuku adalah PT. Bahari Cakrawala Sebuku (PT. BCS) pada tahun 1997. Kemudian disusul oleh PT. Sebuku Iron Lateritic Ores (PT. SILO) pada tahun 2004. 
PT. BCS mendapatkan izin mengeksploitasi batu bara dan menghasilkan 3 juta ton per tahun. Kepemilikian PT. BCS adalah $20 \%$ Indonesia dan $80 \%$ Singapura.

Seperti riset yang dilakukan Puspitasari (2010), bahwa sebelum kedatangan PT. BCS ke Desa Kanibungan sebagian besar masyarakat menggantungkan hidupnya dari perkebunan kelapa sawit dan karet. Kompensasi yang harus diberikan PT. BCS untuk kebun aktif hanya sebesar Rp 600 per meter per segi. Pada kebun yang tidak aktif dihargai Rp 350 per meter persegi dan bekas ladang sebesar Rp 150 per meter persegi. Hal ini sangat tidak sebanding dengan resiko ekonomi masyarakat yang terpaksa menjual tanahnya. Hingga akhirnya masyarakat Kanibungan melakukan protes dan ganti rugi menjadi Rp 1000 per meter persegi dari harga sebelumnya sebesar Rp 150 per meter persegi. Meski demikian hal ini tidak sebanding dengan ketidakpastian sosial ekonomi di masa depan bagi masyarakat Kanibungan.

Begitu pula dengan PT. SILO. Menurut Puspitasari (2010), bahwa perusahaan tambang yang mendapatkan izin eksploitasi untuk bijih besi membawa perubahan besar bagi sosial ekonomi masyarakat Desa Rempa. Perusahaan bijih besi ini masuk ke Pulau Sebuku atas pendekatan kepada elit lokal seperti tokoh pemerintahan dan tokoh agama. Selain itu PT. SILO melakukan pendekatan kepada ketua kelompok sawit. Sebelumnya masyarakat setempat yaitu masyarakat Desa Rempa mengalami kesulitan atas pemasaran produk kelapa sawit. Ajuan yang diberikan PT SILO, dianggap sebagai pilihan terbaik oleh masyarakat Rempa. Namun yang sebenarnya terjadi adalah sebuah penyingkiran kepada masyarakat atas sumber daya penghidupan oleh perusahaan pertambangan.

Tersingkirnya masyarakat pedesaan atas moda produksi tanah merupakan salah satu proses terjadinya kemiskinan pada masyarakat. Seperti hasil-hasil riset sebelumnya baik dalam negeri maupun kasus luar negeri bahwa perampasan tanah oleh pihak negara dan swasta mengakibatkan hilangnya mata pencaharian sebagai petani bagi masyarakat. (SAINS dan STPN, 2009; Scott, 2012; Cademartori, 2002; Freudenburg, 1992 dalam O’Faircheallaigh, 2013).

Sistem ganti rugi atas tanah yang diberikan oleh pihak industri pertambangan mengakibatkan perubahan akses masyarakat atas sumberdaya agraria. Tanah yang sebelumnya diakses dan dimanfaatkan oleh masyarakat berpindahtangan dan dikuasai perusahan tambang. Masyarakat kehilangan akses pemanfaatan tanah garapannya. Meskipun pemindahan kekuasaan tanah tersebut melalui pemberian kompensasi oleh perusahaan tambang namun jumlahnya tidak sebanding dengan keberlanjutan penghidupan masyarakat. Masyarakat telah kehilangan tanah yang selama ini menjadi sandaran hidup. Hal ini dikatakan oleh Peluso (2006) penguasaan yang dilakukan oleh negara dan swasta atas tanah adalah pemiskinan pada masyarakat. Hal ini dimungkinkan kalangan kelas atas di pedesaan jatuh menjadi kelas bawah akibat kehilangan tanah seperti yang diungkapkan (Paige,1975).

Ketika itu masyarakat telah jatuh miskin karena tidak dapat lagi menggantungkan hidupnya pada sumberdaya lahan. Minimal masyarakat hanya bekerja sebagai buruh di perusahaan yang pendapatannya tidak seberapa. Meski tidak dipungkiri jika landasan teori ekonomi liberal, seperti yang diungkapkan Aragon dan Rud (2009), Stedman et al (2004) dalam O'Faircheallaigh (2013), bahwa penelitian kontemporer menunjukkan bahwa daerah dengan ketergantungan tinggi pada pertambangan cenderung meningkatkan pendapatan. Namun pernyataan tersebut perlu dikritisi karena menurut Erman (2005), bahwa yang mendapatkan keuntungan besar dapat digolongkan sebagai pendatang yang memiliki akses politik dan kompetensi yang tinggi, sehingga masuknya pendatang memungkinkan munculnya struktur kelas yang baru dengan basis harta kekayaan.

Terdapat dua pertanyaan dalam penelitian ini, yaitu: (1) bagaimana proses industrialisasi pertambangan di Pulau Sebuku? dan (2) bagaimana dinamika kemiskinan masyarakat akibat industrialisasi pertambangan di Pulau Sebuku?

\section{METODE PENELITIAN}

Penelitian ini dilakukan pada masyarakat Desa Sarakaman, Kecamatan Pulau Sebuku, Kotabaru, Kalimantan Selatan. Penelitian dilakukan pada Bulan Mei - Juni 2014. Penelitian ini menggunakan teknik penelitian seperti observasi partisipan, melalui indepth interviews (wawancara mendalam), diskusi kelompok, studi literatur/ dokumen, maupun partisipasi dalam kegiatan masyarakat. Untuk mendukung kelancaran penggunaan teknik tersebut, peneliti tinggal di dalam (bersama masyarakat Pulau Sebuku). Dalam upaya memaknai setiap hasil pengambilan data di lokasi penelitian. Peneliti perlu melakukan kontemplasi dari setiap kejadian setiap harinya dan dituangkan dalam catatan harian. Hal ini mempermudah peneliti untuk memahami realitas (Denzin dan Lincoln, 2009). Subjek penelitian dipilih secara sengaja (purposive). Selain itu juga peneliti perlu mempertimbangkan variasi informan (maximum variety sampling). Teknik ini menurut Patton (1990) dalam Denzin dan Lincoln (2009) mampu menerangkan dua tipe data yaitu: pertama, deskripsi kasus berkualitas tinggi yang sangat berguna dalam proses pendokumentasian keunikan-keunikan data. Kedua, polapola kemiripan yang sama terbentuk dari semua responden yang dipilih.

\section{HASIL DAN PEMBAHASAN}

\section{Proses Masuknya Perusahaan Pertambangan di Pulau Sebuku}

Pulau Sebuku merupakan pulau kecil yang sekaligus salah satu kecamatan di Kabupaten Kotabaru, Kalimantan Selatan. Luas Pulau Sebuku hanya 224,5 km persegi. Pulau Sebuku terdiri dari delapan desa dengan keseluruhan penduduk 7.212 jiwa dan kepadatan 29 jiwa per km persegi (Kecamatan dalam Angka Pulau Sebuku, 2010). Dimana dua desa yaitu Kanibungan yang berada di Selatan dan Rampa yang berada di Utara Pulau Sebuku berdiri dua industri pertambangan besar yaitu PT BCS dan PT SILO. Menurut Peraturan Menteri Kelautan dan Perikanan RI Nomor 20/MEN/2008 tentang pemanfaatan pulau-pulau kecil dan perairan di sekitarnya, dijelaskan pada pasal 3 ayat 1 , bahwa pulau kecil dan perairan di sekitarnya diprioritaskan untuk salah satu atau lebih kepentingan, yaitu: konservasi; pendidikan dan pelatihan; penelitian dan pengembangan; budidaya laut; pariwisata; usaha perikanan dan kelautan secara lestari; pertanian organik; dan peternakan.

Namun pada ayat 2 di pasal yang sama dijelaskan bahwa, pemanfaatan pulau-pulau kecil dan perairan juga dapat dimanfaatakan antara lain untuk usaha pertambangan, 
permukiman, industri, perkebunan, transportasi dan pelabuhan. Selanjutnya di ayat ke 3 dijelaskan bahwa, pemanfaatan untuk pertambangan wajib sesuai dengan rencana zonasi; memenuhi persyaratan pengelolaan lingkungan; memperhatikan kemampuan sistem tata air setempat dan menggunakan teknologi yang ramah lingkungan. Berdasarkan peraturan ini lah industri pertambangan dapat melakukan penambangan di pulau kecil seperti Pulau Sebuku. Peraturan menteri mengharuskan pemanfaatan untuk pertambangan sesuai dengan rencana zonasi. Sedangkan rencana zonasi Kabupaten Kotabaru disusun pada tahun 2013, jauh setelah Peraturan Menteri dikeluarkan bahkan sangat jauh setelah perusahaan pertambangan berdiri di Pulau Sebuku, artinya keberadaan kedua perusahaan di Pulau Sebuku semakin dikukuhkan dengan dikeluarkannya Peraturan Menteri dan Rencana Zonasi tersebut.

Berdasarkan penelitian sebelumnya oleh Puspitasari (2010), masuknya perusahan tambang untuk pertama kali di Pulau Sebuku adalah PT BCS pada tahun 1997. PT BCS mendapatkan izin mengeksploitasi batubara melalui SK Bupati No. 142/1997 dan menghasilkan 3 juta ton per tahun. Kepemilikian PT BCS adalah $20 \%$ Indonesia dan $80 \%$ Singapura. Kemudian disusul oleh PT SILO pada tahun 2004. Perusahaan bijih besi ini masuk ke Pulau Sebuku atas pendekatan kepada elit lokal seperti tokoh pemerintahan dan tokoh agama. Selain itu, PT SILO melakukan pendekatan kepada ketua kelompok sawit.

Sebelumnya masyarakat setempat yaitu masyarakat Desa Rampa mengalami kesulitan atas pemasaran produk kelapa sawit. Maka ajuan yang diberikan PT SILO, dianggap sebagai pilihan terbaik oleh masyarakat Rampa. Saat ini kedua perusahaan pertambangan telah mememperluas areal tambangannya. PT BCS memiliki areal pertambangan meliputi desa Sekapung, Kanibungan, Mandin, Belambus dan Sarakaman. Kemudian PT SILO kini telah memiliki areal pertambangan meliputi desa Tanjung Mangkok, Rampa, Sungai Bali, Sarakaman dan Belambus.

Di Desa Sarakaman perluasan areal tambang batubara dilakukan PT BCS melalui PT Metalindo Bumi Raya (PT MBR) yang mendapatkan kuasa pertambangan (KP) seluas 1.248,81 hektar untuk eksploitasi. Perluasan KP tersebut berdasarkan SK Bupati Kotabaru Nomor 545/56.1/KP/D. PE pada tanggal 6 Desember 2004 seluas 198.91 hektar, ditambah dengan SK Bupati Kotabaru Nomor 545/11.1/ KP/D.PE pada tanggal 25 Oktober 2007 seluas 1.049 hektar. KP yang didapatkan PT MBR meliputi areal pemukiman masyarakat. Terdapat 3 perkampungan masyarakat Desa Sarakaman yang masuk KP PT MBR yaitu Kampung Pasar, Kampung Baru dan Kampung Sungai Dungun. Namun KP yang dimiliki oleh PT MBR terjadi tumpang tindih dengan KP PT SILO. Proses persidangan juga dilakukan sampai Jakarta yang akhirnya dimenangkan oleh PT MBR kerena potensi yang berada dikawasan tersebut adalah batubara. Keberadaan PT MBR tidak bertahan lama hingga akhirnya KP yang dimiliki dijual kepada PT BCS. Hal tersebut dikarenakan PT MBR yang didirikan oleh salah satu konsultan PT BCS terpaksa menutupnya akibat habisnya modal. Namun persepsi masyarakat berbeda, hal tersebut dianggap masyarakat sebagai strategi perusahaan untuk melupakan janji-janji manis PT MBR saat pembebasan perkampungan. Masyarakat tidak memiliki akses untuk menuntut janji perusahaan karena telah berganti kepemilikan. PT BCS melanjutkan proses pembebasan rumah dan lahan masyarakat yang berada di
KP perusahaan.

PT SILO mendapatkan KP Eksplorasi berdasarkan SK Bupati Kotabaru Nomor 545/11.3/KP/D.PE pada tanggal 27 Februari 2004 dengan luas areal 9.771 hektar. Dari luas lahan yang ada ini telah keluar SK Bupati Kotabaru Nomor 545/06.I/KP/D.PE pada tanggal 30 April 2007 tentang KP Eksploitasi Kode Wilayah KTB.0704KP0016 seluas 4.121,14 hektar dan SK Bupati Kotabaru Nomor 545/06.A.KP/D.PE pada tanggal 30 April 2007 tentang Kuasa Pertambangan, Pengangkutan dan Penjualan Kode Wilayah KTB.0704KP0016. Sebulan kemudian PT SILO kembali mendapatkan KP Eksploitasi seluas 3.365 hektar tepat pada tanggal 2 Mei 2007 melalui SK Bupati Kotabaru Nomor 545/07.I/KP/D.PE dan SK Bupati Nomor 545/07.A/ KP/D.PE tentang Kuasa Pertambangan, Pengangkutan dan Penjualan Kode Wilayah KTB.0704KP0017. Pada tanggal 15 Mei 2007, PT SILO kembali mendapatkan KP seluas 600,65 hektar melalui SK Bupati Kotabaru Nomor 545/08.I/ KP/D.PE dan SK Bupati Kotabaru Nomor 545/08.A/ KP/D.PE tentang Kuasa Pertambangan, Pengangkutan dan Penjualan Kode Wilayah KTB.0705KP0020. Hingga akhirnya KP PT SILO digabung menjadi satu, sesuai dengan SK Bupati Kotabaru Nomor 545/07/IUPOP/D. $\mathrm{PE} / 2010$ pada tanggal 11 Maret 2010 tentang Persetujuan Penyesuaian dan Penggabungan IUP Operasi Produksi dengan Kode Wilayah KTB 1003IUPOP0010 seluas $8.086,8$ hektar. Areal pertambangan PT SILO ternyata sebagian besar berada pada kawasan Hutan Produksi dan Hutan Produksi Konversi. Untuk memperlancar aktivitas pertambangan Kementerian Kehutanan mengeluarkan Izin Pinjam Pakai Kawasan Hutan (IPPKH) seluas 1.731,61 hektar melalui Keputusan Menteri Kehutanan Nomor 372/ Menhut-II/2010.

Sosialisasi masuknya PT SILO tidak dilakukan kepada seluruh masyarakat Pulau Sebuku. Sosialisasi hanya sebatas pada elit desa dan masyarakat yang mendapatkan penggantian lahan. Masyarakat yang kehilangan lahan mendapatkan ganti rugi dan juga dibuka akses untuk bekerja di PT SILO pada awal berdirinya. Namun belakangan banyak masyarakat lokal yang diberhentikan karena tutupnya PT BUMA kemudian berganti PT BMR sebagai kontraktor PT SILO. Pergantian kontraktor di PT SILO mempengaruhi syarat untuk dapat bekerja seperti ijazah pendidikan setingkat SMA. Hal ini tentu merugikan masyarakat lokal, karena sebagian besar masyarakat lokal berpendidikan tingkat SD. Meskipun ada aturan sebuah perusahaan harus sebagian besar mempekerjakan putra daerah. Namun istilah putra daerah mencakup juga pada masyarakat dari Pulau Laut yang cenderung memiliki akses pendidikan yang tinggi dibandingkan masyarakat Pulau Sebuku.

"Kami masyarakat Pulau Sebuku sakit mase. Kami ini kan putra daerah, orang dari kotabaru juga putra daerah. Nah bedanya kalau putra daerah seperti kami pendidikan kada yang tinggi. Ya jelas pang, perusahaan banyak ambil tenaga kerja dari kotabaru." (Pak MNI)

Pada tahun 2000 PT BCS mampu mempekerjakan 50 persen masyarakat Kanibungan di bawah kontrol perusahaan kontraktor PT BUMA. Namun setelah PT. BUMA digantikan oleh PT. PAMA regulasi ketenagakerjaan berubah dan menjadi penghambat masuknya masyarakat untuk bekerja di PT. BCS, bahkan terjadi pemecatan akibat regulasi yang baru. 
Sistem perekrutan tenaga kerja di kedua perusahaan yang berada di Pulau Sebuku semakin mempersempit akses masyarakat lokal untuk bekerja. Dari segi keterampilan sebenarnya pekerja lokal tidak kalah dengan pekerja pendatang. Namun persyaratan yang ditentukan perusahaan mempersempit kesempatan masyarakat lokal untuk dipekerjakan oleh perusahaan seperti syarat pendidikan tingkat SMA dan batasan umur maksimal 25 tahun. Selain itu, aturan untuk mempekerjakan putra daerah oleh perusahaan ternyata tidak banyak menolong masyarakat lokal Pulau Sebuku untuk dapat dipekerjakan. Karena seperti yang diketahui bahwa putra daerah mencakup tidak hanya masyarakat Pulau Sebuku, melainkan juga masyarakat yang berasal dari Pulau Laut yang cenderung memiliki akses pendidikan SMA yang lebih baik. Temuan penelitian ini membuktikan bahwa masuknya industri pertambangan di Pulau Sebuku merupakan keputusan elit pemerintah tanpa mempertimbangkan kepentingan masyarakat lokal. Selain itu, penelitian ini memperkuat pernyataan Erman (2005), bahwa sistem perekrutan tenaga kerja oleh industri pertambangan cenderung merugikan kepentingan masyarakat lokal.

Sejak tahun 2010 PT BCS melakukan perluasan areal pertambangan di Desa Sarakaman. PT BCS sebelumnya melakukan pengerukan batubara di wilayah Selatan Pulau Sebuku dan terus merambat ke wilayah Utara Pulau Sebuku termasuk Desa Sarakaman. Guna mendukung peningkatan pendapatan batubara, PT BCS membangun jalan pertambangan yang melintasi Kampung Pasar, Kampung Baru dan Kampung Sungai Dungun di Desa Sarakaman. Sebelum perusahaan melakukan pembebasan, Kampung Pasar merupakan pusat pemerintahan, ekonomi, pendidikan, kesehatan dan pemukiman di Desa Sarakaman. Pada tahun 2010 Kampung Pasar dipindahkan oleh PT BCS. Begitu juga dengan Kampung Baru yang letaknya bersebelahan dengan Kampung Pasar juga dipindahkan. Kampung Sungai Dungun yang sebelumnya adalah pusat pemukiman dan ekonomi juga dipindahkan. Fasilitas desa dan masyarakat dari ketiga kampung tersebut dipindahkan ke Kampung Sarakaman Maju Mandiri. Tentunya penggusuran ketiga kampung tersebut memunculkan permasalahan dari segi sosial dan ekonomi di masyarakat. Proses ganti rugi yang dilakukan PT BCS banyak dirasakan adanya kecurangan, keganjilan dan ketidakadilan oleh masyarakat. Hingga saat penelitian dilakukan, pembebasan ketiga kampung di Desa Sarakaman masih belum selesai.

\section{"Kami yang masih di sini. Ngga mau jual karena harganya belum cocok, terus juga teras rumah sekarang ngga dihitung. Padahal dulu awal pembebasan 2010, teras masuk hitungan, malah sampai batas jembatan. Teras ini buatnya kan pakai uang. Alasannya ngga jelas. Tapi katanya karena ngga ada dinding. Masa teras didindingi?" (Pak HRL)}

Sejak tahun 2010 PT BCS melakukan pembebasan kepada rumah-rumah milik masyarakat di Kampung Pasar. Pembebasan sudah dilakukan enam kali hingga tahun 2014. Setiap tahap pembebasan menggunakan ketentuan ganti rugi yang berbeda-beda sesuai dengan keinginan PT BCS. Tahap-tahap pembebasan dan aturan-aturannya terlampir. (Lampiran 2)

Sistem ganti rugi yang dilakukan perusahaan kepada masyarakat atas pembebasan rumah dan tanah garapan masyarakat sangat merugikan masyarakat. Harga ganti rugi atas rumah dan tanah garapan masyarakat tidak sebanding dengan resiko ekonomi yang akan dihadapi masyarakat setelah meninggalkan rumah dan tanah garapannya. Rumah masyarakat yang sebelumnya dibangun atas pertimbangan akses pada sungai untuk mendukung ekonomi kini telah dibongkar. Tanah garapan yang dulunya dijadikan sandaran hidup kini sudah dikuasai oleh perusahaan. Sedangkan uang yang mereka dapatkan tidak mampu menjadi penopang keberlanjutan hidup, karena pilihan atas usaha masyarakat sangatlah terbatas.

\section{Aksesibilitas Sumberdaya Agraria bagi Masyarakat Miskin di Desa Sarakaman}

Kampung yang dulu ramai kini telah menjadi puingpuing pengharapan. Kalimat itulah yang sekiranya tepat untuk menggambarkan Kampung Pasar, Kampung Baru dan Kampung Sungai Dungun saat ini. Sebagian besar masyarakatnya telah pindah ke Kampung Sarakaman Maju Mandiri. Kampung Pasar hanya menyisakan rumah-rumah kosong, kantor desa, puskesmas, sekolah dasar, kapal-kapal tak terpakai dan semak-semak yang menenggelamkan bangunan tersebut. Bangunan dan benda-benda itu semua menjadi saksi bisu geliat ekonomi, pendidikan, pemerintahan dan kehidupan masyarakat sebelum pembebasan PT BCS.

Pasar yang selalu ramai setiap Senin malam dan Selasa di Kampung Pasar kini sudah tidak ada lagi. Matinya pasar diakibatkan oleh penutupan sungai oleh PT BCS untuk pembangunan jalan pertambangan di atasnya. Hanya ada 2 buah gorong-gorong yang dialiri air sungai. Gorong-gorong yang berdiameter 7 meter hanya dimungkinkan dilewati kapal nalayan dan speed boat. Sedangkan kapal besar yang biasanya dijadikan angkutan oleh pedagang dari Kotabaru tidak mampu menembusnya. Bahkan di Kampung Sungai Dungun, sungai ditutup dengan menggunakan goronggorong yang sangat kecil. Tidak hanya kapal besar yang tidak dapat melintas, melainkan juga kapal-kapal kecil milik nelayan.

\section{"Sungai ditutup saat pembebasan rumah belum selesai semua. Padahal perjanjiannya kalau sudah dibebaskan semua, baru sungai ditutup." (Pak HRL)}

Pelabuhan di Sungai Dungun sudah tidak berfungsi seperti sebelumnya. Pelabuhan baru dibangun oleh PT BCS berjarak $1 \mathrm{~km}$ dari Kampung Sungai Dungun. Hal ini mempersulit aktivitas nelayan yang sebelumnya dapat dilakukan di depan rumah seperti memperbaiki jaring, mengeringkan perahu dan mengangkut es balok.

\footnotetext{
"Dulu kan perahu langsung ada di depan rumah. Kalau kita beli es balok untuk ikan. Harus mikul jauh sampai rumah dari pelabuhan. Jadi sulit mas." (Pak HRL)

"Dulu pasar ramai pedagang dari Kotabaru. Ada 4 kapal besar berlabuh. Mereka bawa sayur, baju, mainan, kaset-kaset, perabotan. Sekarang sudah ga ada lagi." (Pak ADL)
}

Pembangunan yang dilakukan PT BCS untuk memperlancar aktivitas pertambangannya bukan hanya membuat jalan dan membangun gorong-gorong saja. Pembuatan aliran sungai baru juga dilakukan. Hal tersebut mereka lakukan karena aliran sungai sebelumnya dijadikan untuk areal pengerukan batubara. Dahulu masyarakat menempuh sungai selama 
15 menit hingga laut. Namun kini hanya membutuhkan 5 menit saja.

\begin{abstract}
"Dulu aku 15 menit sampai laut. Tapi sekarang 5 menit saja. Karena dulu sungainya itu berkelok-kelok. Sekarang tinggal lurus aja mas." (Pak MUG)
\end{abstract}

Waktu tempuh menuju laut yang hanya membutuhkan 5 menit saja ternyata tidaklah menguntungkan. Melainkan menjadi bencana atas sumber penghidupan nelayan. Sungai yang pada tahun 2003 menghidupi ikan-ikan. Kini sudah tidak ada ikan lagi. Hal tersebut karena perubahan ekosistem sungai sejalan dengan pembangunan PT BCS di daerah aliran sungai.

"Tahun 2003 aku masih bisa mancing di sini. Lumayan ikannya buat makan sehari-hari. Sekarang kadeda (tidak ada).” (Pak MUG)

Berbeda halnya dengan Kampung Sungai Dungun. PT BCS menutup sungai dengan menggunakan gorong-gorong yang tidak dapat dilewati kapal sekecil apa pun. Sampai akhirnya PT BCS melakukan pembangunan pelabuhan baru sebagai ganti sungai yang ditutup. Hanya saja jarak pelabuhan baru dirasakan menyulitkan aktivitas nelayan yang masih tersisa di Kampung Sungai Dungun.

\begin{abstract}
"Mau ke pelabuhan dari sini $1 \mathrm{~km}$, kami kan butuh bensin juga buat ke sana. Jadi dulu masyarakat minta gorong-gorong yang besar. Jadi kapal bisa lewat. Tapi ini gorong-gorong kecil. Kapal ngga bisa lewat. Malah sungai ditutup. Malah katanya pelabuhan mau digeser lagi. Kaya apa nanti nelayan. Makin susah." (Pak SLD)
\end{abstract}

Selain itu pemindahan pelabuhan juga menimbulkan permasalahan lain bagi nelayan. Nelayan membutuhkan air bersih untuk merendam udang hasil tangkapan. Perusahaan sebelumnya telah berjanji akan mengalirkan air bersih ke pelabuhan. Namun hingga saat ini pelabuhan baru tidak tersedia air bersih.

\begin{abstract}
"Kami nelayan butuh air bersih di pelabuhan, itu kan untuk udang, ikan. Tapi air bersih kadeda. Jadi kami terpaksa pake air asin. Jadi kami ngga bisa menampung lama-lama. Udang bisa berubah warna merah. Berapa jadinya harganya?jatuh. Dulu kita bisa simpan 3 hari." (Pak SLD)
\end{abstract}

Kampung Sarakaman Tengah merupakan kampung yang sebagian besar masyarakatnya menggantungkan hidupnya pada hutan dan kebun karet. Sebagian besar masyarakat bekerja sebagai penoreh karet baik menoreh di kebun karetnya sendiri atau kebun karet orang lain dengan sistem bagi hasil (2:1). Dua bagian untuk penoreh karet dan satu bagian untuk pemilik kebun. Kebun karet yang dimiliki masyarakat adalah peninggalan generasi sebelumnya. Asset Masyarakat Harga Ganti Rugi dari PT SILO

\begin{tabular}{ll}
\hline Tanah & Rp 1.500 per meter \\
Pohon Karet Kampung & Rp 60.000 per pohon \\
Pohon Durian, Cempedak, & Rp $500.000-$ Rp 1.000 .000 per \\
Duku dan sebagainya & pohon \\
\hline
\end{tabular}

Usia kebun karet sudah 30 tahun. Jenis karet yang dimiliki adalah karet kampung. Karet kampung tersebut memiliki kualitas getah yang lebih baik dan dibandingkan jenis karet unggul. Selain itu karet kampung memiliki usia yang jauh lebih lama dibandingkan karet unggul.

"Di sini karet kampung semua. Umurnya tua-tua. Kalau karet kampung bisa hidup 60 tahun lebih. Kalau karet unggul 20 tahun juga sudah mati." (Pak SDN)

Harga karet kering tidak lebih dari Rp 5.000 per kilonya. Meski demikian masyarakat Kampung Sarakaman Tengah tetap menjalankannya untuk menyambung hidupnya. Kampung Sarakaman Tengah ini tidak seperti Kampung Pasar, Kampung Baru dan Kampung Sungai Dungun yang mendapatkan pembebasan oleh PT BCS karena berada di bagian hutan tidak seperti ketiga kampung yang berada di Daerah Aliran Sungai. Sebenarnya masyarakat memiliki kebun-kebun karet yang potensial akan bijih besinya. PT SILO sempat melakukan penawaran atas kebun-kebun masyarakat. Namun tidak ada satu pun masyarakat yang mau menjualnya, masyarakat menyadari akan pentingnya tanah yang mereka miliki untuk keberlanjutan hidup. Sedangkan harga tanah hanya Rp 1.500 permeter dan harga tumbuh tanam Rp 60.000 per batang pohon karet maskimal Rp 1.000.000 per pohon durian sesuai kesepakatan. Jika menjual tanah beserta tanaman yang tumbuh maka sejumlah besar uang akan mereka terima. Namun yang menjadi pertimbangan masyarakat bahwa tanah adalah segalanya untuk menghidupi hingga generasi selanjutnya.

"Kalau kita jual tanah, dihitung-hitung rugi mas. Harganya ngga seberapa. Tapi hidup selanjutnya kita mau kerja apa. Kebun karet saya itu buat jaga-jaga kalau nanti sudah ngga kerja di perusahaan lagi." (Pak SDN)

\section{Tabel 1. Asset Masyarakat dan Harga Ganti Rugi dari PT SILO, 2014}

Masyarakat Kampung Sarakaman Tengah sebagian bekerja sebagai pegawai perusahaan, baik di PT BCS maupun PT SILO. PT SILO lebih banyak menyerap tenaga kerja dari masyarakat Sarakaman Tengah dari pada PT BCS. Namun dari segi penghasilan yang diperoleh masyarakat lebih besar jika bekerja di PT BCS sebesar Rp 4.000.000 per bulan tanpa ada hari libur setiap minggunya. Dibandingkan penghasilan bekerja di PT SILO sebesar Rp 1.500.000 per bulan. Mengingat sejak tahun 2013 PT SILO tidak dapat melakukan penjualan bijih besi mentah terkait dengan kebijakan baru ESDM.

"Sebelumnya saya berkebun karet. Karena harganya jatuh, dari tahun 2012 saya bekerja jadi security di Lagan subkonnya BCS. Tapi kayanya kerja di kebun itu lebih enak, kita bebas mau bekerja. Kalau sekarang di perusahaan kita ada jam kerjanya. Gaji 4 juta cukup untuk makan sehari-hari. Kalau di Jawa uang 4 juta mungkin besar mas. Tapi di sini ngga ada apaapanya." (Pak SDN)

Selain bekerja berkebun karet dan bekerja di perusahaan. Sebagian kecil lainnya, masyarakat hidup dengan menyenso (mencari kayu). Kayu yang dicari berasal dari tanah milik sendiri ataupun di tanah milik PT SILO. Pekerjaan menyenso dilakukan saat ada pesanan dari masyarakat yang ingin membangun rumah. Kayu di jual per kubik dengan harga Rp 1.500.000. Pohon-pohon yang berada di atas tanah PT SILO juga sering dimanfaatkan oleh 
masyarakat Kampung Sarakaman Tengah. Hal tersebut dilakukan masyarakat, kerena mereka berpendapat tidak akan lama lagi pohon-pohon tersebut akan dirobohkan PT SILO untuk mengeruk tanahnya.

\section{"Dari pada kebuang, jadi kita ambil saja kayu- kayunya. Karena biasanya SILO main robohin saja pohonnya, banyak yang patah-patah tidak terpakai. Kita juga boleh sama SILO asal tidak untuk dijual ke luar pulau." (Pak MNH)}

Sebenarnya untuk penebangan pohon dilarang oleh pihak kehutanan. Penebangan pohon yang dilakukan oleh masyarakat dianggap berkontribusi merusak lingkungan. Padahal aktivitas pertambangan sangat jelas sangat merusak lingkungan. hutan-hutan yang dulunya berstatus hulan lindung kini telah menjadi KP pertambangan. Pihak perusahaan yang menguasai hutan tersebut tidak menampilkan sikap yang jelas apakah masyarakat diperbolehkan memanfaatkan kayu-kayu atau tidak. Namun yang sekarang berlangsung adalah masyarakat melakukan pengambilan kayu di tanah milik perusahaan. Hasil kayu dapat dijual ke pihak lain yang masih berada di Pulau Sebuku dan menjual ke perusahaan.

PT BCS dan pemerintah Desa Sarakaman merancang kampung relokasi yang letaknya di tengah-tengah desa yang bersebelahan dengan Kampung Sarakaman Tengah. Kampung relokasi ini sengaja dibuat untuk menggantikan kampung yang mendapat pembebasan seperti Kampung Pasar, Kampung Baru dan Kampung Sungai Dungun. Fasilitas pemerintahan, kesehatan, pendidikan ekonomi dan pemikiman kembali di bangun di relokasi ini.

Masyarakat yang tinggal di Kampung Sarakaman Maju Mandiri, merupakan masyarakat yang berasal dari Kampung Pasar, Kampung Baru dan Kampung Sungai Dungun. Sehingga sebagaian masyarakatnya adalah nelayan. Aktivitas nelayan oleh masyarakat di Kampung relokasi ini dirasa menjadi berat karena jarak dari tempat tinggal ke pelabuhan sangat jauh. Hal ini mempengaruhi hasil tangkap nelayan, pengeluaran dan juga waktu yang dikorbankan lebih besar oleh nelayan. Selain nelayan masyarakat Kampung relokasi terutama perempuan bekerja sebagai penyadap karet. Kemudian sebagian lagi bekerja sebagai karyawan di perusahaan PT SILO maupun PT BCS sebagai satpam dan supir. Yang terakhir sebagian kecil masyarakat di Kampung relokasi bekerja menyenso atau mencari kayu di hutan. Hutan yang dimafaatkan oleh masyarakat adalah bukan lahan milik mereka melainkan milik kehutanan dan PT SILO.

Masyarakat Sarakaman telah mengalami perubahan dari segi sosial maupun ekonomi semenjak pembebasan lahan kebun maupun rumah masyarakat. Pembebasan di Sarakaman dilakukan oleh dua perusahaan tambang yaitu PT BCS dan PT SILO. PT BCS melakukan pembebasan di sebelah Barat Desa Sarakaman. Hal ini mengakibatkan perkampungan di Barat Sarakaman seperti Kampung Pasar, Kampung Baru dan Kampung Sungai Dungun harus dibongkar dan dipindahkan. Namun proses pembebasan rumah masyarakat belum selesai sepenuhnya. Masih ada sebagian masyarakat yang bertahan di kedua kampung tersebut. Meski demikian, perusahaan PT BCS sudah melakukan aktivitas pertambangan di dekat Kampung tersebut seperti melakukan blasting yang berjarak hanya 150 meter dari kampung Sungai Dungun, melakukan penutupan sungai dan pemindahan pelabuhan. Hal ini mengakibatkan nelayan merasakan kesulitan mengakses pelabuhan, dibandingkan sebelumnya mereka dapat beraktivitas sebagai nelayan langsung dari depan rumahnya. Mereka yang tersisa di Kampung Pasar, Kampung Baru dan Kamoung Sungai Dungun merasakan ketersingan. Kampung yang sebelumnya ramai. Geliat ekonomi yang tinggi, kini sudah tidak ada lagi. Warung-warung yang dulu banyak berdiri di kedua kampung kini hanya bertahan satu warung dengan perputaran uang yang rendah karena pembeli yang berkurang. Selain itu pengumpul ikan yang biasa membutuhkan es batu dari Kotabaru. Harus mengangkat es batu dari pelabuhan ke rumah yang berjarak $1 \mathrm{~km}$ dan kembali membawanya ke pelabuhan untuk di bawa ke Kotabaru. Kemudian kerusakan jaring nelayan, yang dulu bisa dikerjakan disela-sela waktu santai di depan rumah bisa diselesaikan sehari. Kini karena keterbatas waktu dan jarak dari rumah. Aktivitas memperbaiki jaring dilakukan bukan di sela-sela waktu karena jauh dari tempat tinggal. Sehingga untuk memperbaiki jaring yang rusak membutuhkan waktu 2 sampai 3 hari. Hal ini tentunya mengurangi waktu mencari ikan di laut dan mempengaruhi pendapatan nelayan.

Bagi masyarakat dari Kampung Pasar. Kampung Baru dan Kampung Sungai Dungun yang mendapatkan pembebasan tentunya membawa perubahan sosial dan ekonomi mereka. Minimal mereka mendapatkan Rp 100.000.000 untuk rumah mereka dengan harga Rp 1.800 .000 per meter. Meski demikian mereka harus mengeluarkan sebagian uangnya untuk membangun kembali rumahnya di daerah Kampung relokasi. Sedangkan sisanya, mereka pergunakan untuk kebutuhan sehari-hari dan mendukung aktivitas semula sebagai nelayan. Karena lokasi relokasi dengan pelabuhan sangat jauh maka memaksa mereka membeli sepeda motor. Dalam kesehariannya mereka membutuhkan bensin yang terbilang mahal di Pulau Sebuku yaitu Rp 9.000 per liter. Uang yang mereka dapatkan tidak seberapa tapi aktivitas ekonomi mereka semakin sulit.

"Masyarakat mau menjual rumah mereka karena terdesak atas keperluan mereka terutama ketika anggota keluarga sakit dan juga pengharapan atas uang yang besar akan didapat, hingga akhirnya masyarakat merasakan kalau uang tidak berarti apaapa dibandingkan sulitnya aktivitas bernelayan." (Pak SLD)

Kampung relokasi yang bernama Sarakaman Maju Mandiri yang direncanakan oleh elit desa dan perusahaan ternyata tidak berjalan sebagaimana yang diinginkan. Pusat ekonomi yang diinginkan bergeliat di kampung relokasi ini tidak seperti dahulu sebelum pemindahan pasar pada tahun 2010. Bangunan pasar di tengah-tengah kampung relokasi kosong setiap harinya kecuali di hari Minggu.

"Sekarang pasar sepi. Kalau hari Minggu saja. Palingan hanya 4-5 pedagang saja yang jualan dari Kotabaru. Kalau dulu di Kampung pasar ramai dari Senin malam sampai Selasa. Pedagang dari manamana yang beli juga dari mana-mana." (Pak SDN)

Sepinya pasar di kampung relokasi dikarenakan pedagangpedagang yang berasal dari Kotabaru terhambat akses berjualan. Hal tersebut terjadi semenjak pembangunan jalan pertambangan PT BCS dibangun di atas sungai. Gorong-gorong yang mengaliri sungai tidak dapat dilalui 
kapal-kapal besar yang biasa digunakan pedagang. Selain itu jarak dari pelabuhan ke pasar relokasi kurang lebih 3 kilo meter yang hanya dimungkinkan diakses dengan kendaraan mobil bak terbuka. Pedagang dan masyarakat berharap perusahaan mau menyediakan transportasi untuk pengangukatan barang dagangan dari pelabuhan ke pasar relokasi. Namun tidak ada tanggapan dari perusahaan. Pedagang merasa berat untuk mengeluarkan biaya transportasi darat untuk berjualan di pasar relokasi.

Kampung relokasi yang sudah mulai berpenghuni sejak diresmikan tahun 2011. Ternyata memunculkan kesulitan bagi nelayan yang tinggal. Aktivitas ekonomi nelayan menjadi sulit sejak kepindahaannya dari kampung sebelumnya. Kampung sebelumnya memiliki akses sungai yang mendukung aktivitas nelayan. Perahu dan jaring dapat ditemui langsung dari depan rumah. Sekarang nelayan harus menempung 3 kilo meter untuk dapat menuju perahu dan jaringnya. Kerugian waktu, biaya dan tenaga mereka hadapi dalam melakukan aktivitas nelayan seperti melaut, memperbaiki perahu dan jaring. Perahu dan jaring adalah aset berharga yang dimiliki nelayan. Maka upaya untuk menjaga dan merawat aset tersebut kini membutuhkan pengorbanan dan pengeluaran yang besar.

Masyarakat nelayan yang tidak memiliki tanah perkebunan menjadi pihak yang sangat dirugikan terlebih lagi rumah yang sebelumnya akses terhadap sungai kini tidak dimiliki lagi. Berbeda halnya dengan masyarakat yang memiliki perkebunan karet. Masyarakat yang bekerja karet tidak mengalami kesulitan ketika harus menjual rumahnya di daerah aliran sungai. Uang mereka peroleh justru dijadikan modal untuk membuka kebun baru. Seperti halnya masyarakat kampung hutan karet. Kampung hutan karet merupakan pemukiman masyarakat yang baru sejak tahun 2013. Pertama kali rumah dibangun oleh Pak TRJ yang menjabat menjadi ketua RT di Kampung Baru. Rumahnya dibangun di areal hutan karet miliknya. Langkahnya itu diikuti oleh masyarakat lainnya yang juga berasal dari Kampung Baru. Hingga saat ini sudah tercatat 18 rumah sudah didirikan di sana dan akan terus bertambah (saat penelitian berlangsung ada pembangunan rumah baru). Sebagian besar masyarakat Kampung Hutan Karet bekerja sebagai karyawan di perusahaan tercatat ada 6 orang. Kemudian sebagian lagi bermata pencaharian sebagai nelayan sebanyak 5 orang, pedagang 2 orang dan 2 orang penyadap karet. Sedangkan 3 orang sudah tidak mampu bekerja karena usia tua. Namun sebenarnya aktivitas menyadap karet sering kali dilakukan oleh kaum perempuan baik di kebun sendiri maupun di kebun orang lain dengan sistem bagi hasil (2:1).

Masyarakat Hutan Karet, sebenarnya mereka memiliki hak untuk dapat tinggal di Kampung Maju Mandiri yang disediakan oleh perusahaan. Namun mereka yang tinggal di Kampung Hutan Karet memiliki alasan untuk tidak mempergunakan haknya. Di Kampung Hutan Karet, masyarakat dapat menanam pisang, mangga, limau, duku, rambutan, terong, nanas dan tanaman lainnya.

"Kalau di sana kita hanya dapat tanah $10 \times 20$ meter. Kita ngga nanem pohon-pohon di belakang rumah. Sempit, kalau disini kita mau beli tanah berapa luas. Nanem pisang bisa, nanem sayur bisa." (Pak TRJ)

Kampung Hutan Karet ini bersebelahan dengan tanah milik PT SILO. Tanah PT SILO ini masih berupa hutan yang suatu saat akan dilakukan pengerukan bijih besi. Hal tersebut menunjukkan bahwa sebenarnya masyarakat Kampung Hutan Karet memiliki tujuan untuk tinggal di sana. Padahal, mereka memiliki hak untuk membangun rumah di kampung relokasi. Alasan mereka untuk membangun pemukiman di hutan karet bukan semata-mata ingin membuka kebun di belakang rumah. Melainkan ingin mendapatkan keuntungan lebih dari kemungkinan pembebasan selanjutnya yang dilakukan PT SILO. Terlebih tanah yang mereka beli untuk membangun rumah dan kebun terbilang murah yaitu $\mathrm{Rp} 2.000 .000$ seluas $20 \times 10$ meter. Masyarakat membeli kepada Pak SRY yang memiliki kebun karet luas di kawasan tersebut. Kemudian untuk membangun rumah membutuhkan biaya Rp 50.000.000 - Rp 100.000.000. Masyarakat memiliki kemampuan untuk membeli tanah dan membangun rumah di kampung hutan karet setelah mendapatkan uang pembebasan rumah dari PT BCS sebesar Rp 200.000.000. Uang tersebut digunakan untuk membangun rumah yang bersebelahan dengan tanah miliki PT SILO untuk mendapatkan keuntungan lebih dari kemungkinan pembebasan. Selain itu masyarakat membuka kebun di belakang rumah sebagai upaya meningkatkan harga jual dari tanam tumbuh. Seperti yang diketahui sebelumnya harga tanam tumbuh berdasarkan jenis tanaman. Seperti karet dihargai Rp 50.000 per pohon dan tanaman buah seperti durian dihargai Rp 500.000 - Rp 1.000.000 per pohon.

Kalangan kelas bawah seperti nelayan dan penyenso mengalami tekanan akibat pembebasan pihak perusahaan. kalangan masyarakat ini terus tersingkir dari sumber daya yang menjadi sandaran hidupnya. Cukup banyak diantara mereka melakukan aktivitas ekonomi yang bertentangan dengan aturan yang berlaku seperti melakukan penebangan pohon di areal pertambangan. Realita tersebut memperkuat pernyataan Peluso (2006) penguasaan yang dilakukan oleh negara dan swasta atas tanah adalah pemiskinan pada masyarakat.

\section{Perubahan Strategi Nafkah oleh Masyarakat Miskin di Desa Sarakaman}

Awal datangnya masyarakat di Pulau Sebuku adalah karena pelarian dari tanah kelahiran mereka di sungai hulu akibat penjajahan Belanda. Ketidakinginan dijajah oleh Belanda, mereka melakukan pencarian tempat tinggal baru. Sebagai suku Banjar sebelumnya mereka hidup bertani dan berladang di daerah asalnya yaitu di Muara Muning daerah Rantau. Kai-kai ini lah yang menghasilkan keturunan masyarakat Desa Sarakaman.

Suku Banjar identik dengan bertani dan berkebun. Menetapnya masyarakat di Desa Sarakaman dimulai pada tahun 1915 diawali dengan pembukaan hutan untuk menanam lada. Pada saat itu potensi kayu ulin sangat melimpah. Kayu-kayu ulin dimanfaatkan oleh masyarakat untuk membangun rumah dan dijual ke kota. Sampai akhirnya kini sudah tidak ada lagi kayu ulin yang bisa dimanfaatkan masyarakat. Habisnya kayu-kayu ulin semenjak masuknya kedua perusahaan pertambangan yang melakukan eksploitasi bijih besi di tahun 2004. Seperti yang diketahui sebelumnya bahwa aktivitas pertambangan bijih besi yang dilakukan PT SILO berada di kawasan hutan yang berada di sebelah timur Pulau Sebuku. Berikut pengakuan seorang kai yang sudah berumur 80 tahun tentang potensi kayu ulin dulu dan sekarang. 
"Dulu banyak kita cari kayu ulin. Di hutan sebelah timur. Kayunya besar-besar, masyarakat biasa ambil ulin buat rumah. Sekarang kadeda lagi, habis. Kalau masyarakat ambil paling batangnya aja. Kalo perusahaan sampai akar-akar, biji-bijinya pakai eksa." (Pak ANJ)

Sebelum adanya pertambangan masuk di Pulau sebuku, aktivitas mencari kayu-kayu ulin untuk dibawa ke kota ramai dilakukan. Harga kayu ulin ini terbilang sangat tinggi dibandingkan kayu-kayu lain yaitu Rp 1.500.000 per kubik. Awalnya aktivitas ekonomi ini tidak menjadi ancaman bagi keberlanjutan pohon ulin di Pulau Sebuku. Bisnis kayu ternyata semakin ramai, sampai akhirnya pihak kehutanan melarang untuk perdagangan kayu-kayu ulin ke luar Pulau Sebuku. Masyarakat hanya diperbolehkan memanfaatkan kayu untuk kebutuhan di Pulau Sebuku seperti pembangunan rumah. Hingga saat ini kayu ulin sangat sulit didapatkan. Saat ini hanya bersisa bekas tebangan pohon ulin yang bisa dimanfaatkan masyarakat. Ukurannya hanya setengah sampai satu meter. Namun ukuran tersebut dapat dimanfaatkan sebagai tongkat, bagian yang ditancapkan ke tanah sebagai fondasi rumah. Berikut adalah penjelasan tukang bangunan tentang pemanfaatan sisa-sisa kayu ulin.

"Kalau bangun rumah kita harus pakai ulin buat tongkatnya. Kayu ulin ini kuat sampe ratusan tahun. Kena air makin kuat dia. Sekarang ulin susah dicari, nah kaya itu nah, cukup buat jadi tongkat." (sambil menunjuk bekas potongan pohon ulin, seperti gambar di atas) (Pak BRM)

Aktivitas penebangan pohon-pohon ulin yang dulu dilakukan masyarakat, ternyata masih menyisakan bagianbagian yang bisa dimanfaatkan sampai saat ini. Bekas potongan chainsaw oleh masyarakat masih meninggalkan pangkal pohon dan juga akar-akarnya. Bagian inilah yang masih bisa dimanfaatkan untuk tongkat rumah. Namun hal tersebut tidak didapatkan dari aktivitas pertambangan bijih besi yang menghabiskan seluruhnya sampai akar-akar.

Tabel 2. Jenis Kayu, Ukuran dan Harga Jual dari Penyenso di Desa Sarakaman, 2014

\begin{tabular}{lll}
\hline $\begin{array}{l}\text { Jenis } \\
\text { Kayu }\end{array}$ & Ukuran & Harga \\
\hline Ulin & $(400 \mathrm{~cm} \times 10 \mathrm{~cm} \times 10 \mathrm{~cm})$ & Rp 500.000 \\
Meranti & $\begin{array}{l}(400 \mathrm{~cm} \times 20 \mathrm{~cm} \times 1,5 \mathrm{~cm}) \text { sebanyak } \\
62 \text { lembar }\end{array}$ & Rp1.860.000 \\
MC & $\begin{array}{l}(400 \mathrm{~cm} \times 20 \mathrm{~cm} \times 2 \mathrm{~cm}) \text { sebanyak } \\
62 \text { lembar }\end{array}$ & Rp 1.000.000 \\
\hline
\end{tabular}

Kebutuhan kayu ulin sangat sulit didapatkan oleh masyarakat. Penyenso biasa mencari kayu ulin sampai ke hutan sebelah timur Pulau Sebuku. Seringkali masyarakat yang mendapatkan pembebasan rumah, membongkar rumah mereka sebelumnya untuk diambil kayu-kayunya sebagai bahan bangunan rumah barunya. Kemudian untuk menutupi kekurangan bahan bangunan rumah mereka membeli kayu MC (bebas) kepada penyenso. Kualitas kayu $\mathrm{MC}$ jauh lebih rendah dibandingkan kayu ulin. Harganya kayu MC pun murah.

Dalam memenuhi kebutuhan pembangunan rumah saat ini. Masyarakat hanya menggunakan kayu-kayu MC. Kayu MC ini adalah kayu bukan pilihan, tetapi kayu apa saja yang didapatkan oleh pencari kayu. Kayu MC, kini menjadi salah satu pilihan masyarakat untuk membangun rumah. Harga kayu MC terbilang murah dan mudah didapatkan. Dari harga Rp 1.000 .000 per kubik kayu MC penyenso perlu mengeluarkan biaya seperti penyewaan mobil untuk mengangkut kayu sebesar Rp 200.000, bahan bakar Rp 100.000 dan upah angkut kayu Rp 100.000. Bahkan hasil yang didapatkan penyenso harus dibagi dua kepada pemilik chainsaw. Maka uang bersih yang didapatkan oleh penyenso adalah Rp 300.000 per kubik kayu MC. Mereka biasa mulai bekerja dari pukul 09.00 sampai pukul 16.00 WITA.

Bagi penyenso, mencari pesanan kayu MC dapat dicari dari areal KP PT SILO atau perkebunan masyarakat. Aktivtas penyenso di areal perusahaan ini dianggap oleh aparat desa sebagai pelanggaran, karena pihak kehutanan melarang penebangan kayu. Meski demikian masyarakat melakukannya secara terbuka. PT SILO menyadari aktivitas tersebut dilakukan di areal mereka. PT SILO seperti menutup mata atas penebangan kayu oleh masyarakat. Hal ini dipahami perusahaan bahwa suatu saat areal tersebut akan ditambang bahkan tidak bersisa kehidupan. Perusahaan tidak menyatakan secara jelas apakah masyarakat diperbolehkan melakukan penebangan di areal mereka. Berikut penjelasan dari pihak BKSDA tentang penebangan pohon di areal perusahaan.

"Untuk di lahan PT SILO. Masyarakat biasanya menebang pohon-pohonnya. Tapi nanti kayunya di jual ke perusahaan. Ada juga kayunya yang digunakan untuk kebutuhan masyarakat tapi dalam skala kecil. Tapi kalau untuk di jual apalagi di jual ke luar Pulau Sebuku. Itu tidak boleh."

Sikap perusahaan yang demikian menunjukkan pelepasan tanggung jawab atas pelanggaran yang dilakukan masyarakat, selain itu perusahaan tetap mendapatkan keuntungan dengan mendapatkan persediaan kayu untuk kebutuhan pertambangan dari masyarakat. Perusahaan tidak ingin mengambi resiko atas penebangan kayu di wilayah mereka dengan menyatakan secara jelas memperbolehkan masyarakat menebang kayu. Sebenarnya aktivitas penebangan hutan adalah suatu pelanggaran. Pelanggaran tersebut menjadi tanggung jawab kehutanan sepenuhnya. Hal ini terlihat saat pihak kehutanan datang ke Desa Sarakaman, aparat desa mengistruksikan kepada masyarakat untuk tidak melakukan penebangan kayu. Papan-papan yang terlihat dari jalan harus dipindahkan sementara saat kedatangan pihak kehutanan. Pihak kehutanan sempat menangkap masyarakat yang melakukan penebangan kayu oleh masyarakat di wilayah cagar alam. Menurut pengakuan pihak BKSDA Pulau Sebuku, masyarakat memiliki argumen yang sulit terbantahkan.

"Kita pernah menangkap masyarakat yang menebang kayu. Tapi masyarakat pintar mas. Coba sampean pikir, masyarakat bilang gini. (Pak kami ini nebang pohon satu-dua cukup, kami dari dulu memang seperti ini. Tapi perusahaan akar sampai biji-bijinya diambil, tanahnya juga dikeruk). Nah kita mau jawab seperti apa mas?" (Pak EK)

Aktivitas penebangan kayu oleh masyarakat adalah suatu pilihan mereka untuk bertahan hidup. Biasanya aktivitas ini dijalankan oeh mereka yang tidak memiliki perkebunan atau memiliki sebagian kecil perkebunan karet. Karena pendapatan dari hasil karet tidak seberapa karena harga 
yang sangat murah Rp 5.000 per kilo gerah karet. Aktivitas menyenso menjadi pilihan terbaik untuk mendapatkan penghasilan yang lebih baik. Terlebih perusahaan bersikap mengambang atas aktivitas penebangan di arealnya. Selain itu dengan mempertimbangkan kebiasaan masyarakat yang semenjak dahulu mereka hidup dengan memanfaatkan hasil hutan, upaya menghilangkan aktivitas penebangan hutan oleh masyarakat sulit dilakukan. Sebagian besar rumah masyarakat terbuat dari kayu. Berikut adalah renungan pihak BKSDA atas aktivitas penebangan hutan oleh masyarakat.

\section{"Sebenarnya kami sulit untuk mencegah penebangan hutan oleh masyarakat. Karena dari dulu masyarakat hidupnya menebang pohon. Kecuali kita kasih pilihan pekerjaan buat masyarakat, supaya mereka tidak menebang pohon lagi." (Pak EK)}

Kecenderungan masyarakat yang melakukan penebangan hutan adalah masyarakat yang tidak mendapatkan uang pembebasan tempat tinggal oleh perusahaan. Aktivitas ini dilakukan oleh masyarakat dari Kampung Sarakaman Tengah. Kampung Sarakaman Tengah ini memang bukan merupakan wilayah yang harus dibebaskan perusahaan karena keberadaannya jauh dari aktivitas pertambangan. Semenjak pembebasan Kampung Pasar, Kampung Baru dan Kampung Sungai Dungun pembangunan rumahrumah baru semakin ramai oleh masyarakat. Hal ini lah yang menjadikan penebangan kayu juga semakin ramai. Permintaan kayu semakin meningkat. Namun tidak seperti dahulu mereka dapat menggunakan kayu ulin untuk rumah-rumah mereka. Mulai dari tongkat sampai dinding dapat menggunakan ulin. Namun kini hanya tongkat lah yang berasal dari kayu ulin dengan memanfaatkan sisa-sisa tebangan pohon ulin. Bagi masyarakat yang mendapatkan sejumlah besar uang pembebasan mampu mengeluarkan uang yang besar untuk mendapatkan kayu ulin. Bagi penyenso, untuk mendapatkan kayu ulin mereka harus mencari jauh kedalam hutan di sebelah timur. Tentunya kawasan tersebut adalah kawasan milik kehutanan yang tidak diperbolehkan siapapun mengambil kayu-kayunya. Namun karena harga yang tinggi diberikan oleh pemesan penyenso bersedia mencarikannya. Berbeda dengan masyarakat yang mendapatkan sejumlah kecil pembebasan, mereka lebih memilih untuk menggunakan kayu-kayu MC untuk membangun rumah barunya atau dengan menggunakan kembali kayu-kayu dari rumah lama mereka.

Berdasarkan kasus tersebut dapat dikatakan aturan-aturan dari pihak kehutanan akan sulit diterapkan mengingat konteks masyarakat yang sedang berlangsung saat ini. Jika masyarakat menghendaki membangun rumah permanen dengan batu, tidak dimungkinkan melihat keberadaan mereka di pulau kecil. Kebutuhan batu dan pasir sulit dipenuhi. Biaya yang dibutuhkan akan sangat tinggi karena harus mendatangkan bahan-bahan tersebut dari kota. Hanya kayu, pilihan masyarakat untuk membangun rumah mereka kembali. Kemudian pembebasan yang dilakukan perusahaan juga membawa pengaruh besar atas permintaan kayu. Menjadi penyenso adalah pilihan terbaik bagi mereka yang tidak mendapatkan pembebasan dan tidak memiliki atau memiliki sedikit lahan perkebunan.

Belakangan pembangunan rumah di Desa Sarakaman ramai terjadi semenjak pembebasan rumah masyarakat. Hal ini membawa pengaruh besar bagi pekerja bangunan. Pekerjaan bangunan terlepas dari pekerjaan penebang pohon. Pekerja bangunan hanya melakukan pembuatan rumah tanpa harus memikirkan bahan-bahan bangunan seperti kayu. Persediaan kayu untuk bangunan dilakukan antara pemilik rumah dan penyenso. Tukang bangunan dilakukan oleh mereka yang memiliki kemampuan khusus seperti mengukur dan memasang kayu. Sebenarnya hampir semua masyarakat mampu membangun rumah mereka sendiri. Namun aktivitas pembangunan rumah menjadi sebuah profesi sendiri semenjak masyarakat mulai menjalankan pekerjaan yang berbeda-beda. Pekerja bangunan semakin dibutuhkan oleh masyarakat. Pekerja bangunan mendapatkan uang borongan untuk membangun rumah. Seperti salah satu tukang bangunan dari Kampung Sarakaman Tengah.

"Ulun sekarang lagi buat dapur, wc dan tempat masak. Ulun kerja borongan 7 juta untuk buat kamar mandi, we dan dapur. Kayu-kayu sudah ada dari yang punya rumah. jadi kami tinggal ngebangun aja. Ya paling ulun harus ngehalusin papan-papan. Ini papan MC ya kalo." (Pak BRM)

Semenjak pembebasan tempat tinggal masyarakat permintaan pembangunan rumah kepada tukang bangunan semakin meningkat. Beberapa masyarakat melakukan perubahan pekerjaan yang sebelumnya berkebun keret menjadi pekerja bangunan. Pekerjaan ini dianggap cukup menjanjikan di saat Desa Sarakaman ramai pembangunan rumah baru. Biaya pembangunan rumah menjadi semakin meningkat. Seperti yang diungkapkan seorang warga Sarakaman yang membangun rumah barunya.

"Dulu kita membangun rumah 60 juta untuk bayar tukang saja cukup. Tapi sekarang mahal mase. 80 juta uang untuk tukang. Harganya naik setelah pembebasan rumah oleh perusahaan."

Menjadi tukang bangunan dianggap menguntungkan. Terlebih pekerjaan menorah karet tidak lagi menguntungkan. Pedapatan yang bisa dihasilkan dari menoreh karet tidak lebih dari $10 \mathrm{~kg}$ getah per minggu dengan harga jual $\mathrm{Rp}$ 5.000 per kg. Bahkan di saat penelitian berlangsung, rata-rata hujan turun 4 kali per minggu. Artinya kegiatan menoreh tidak dapat dilakukan oleh masyarakat. Tentunya hal ini merugikan bagi penoreh karet. Kondisi ini membuat sebagian masyarakat beralih menjadi tukang bangunan.

Dalam menjalankan pekerjaan membangun rumah biasanya dilakukan oleh 1 sampai 2 pekerja. Sehingga uang dihasilkan dianggap lebih dari cukup. Untuk membangun sebuah rumah biasanya dilakukan dengan sistem borong dengan targetan waktu tertentu. Biasanya untuk menyelesaikan sebuah rumah membutuhkan waktu kurang lebih dari 4 bulan oleh satu orang pekerja. Artinya uang yang dihasilkan dari pekerjaan membangun rumah jauh lebih besar dibandingkan menoreh karet. Uang yang didapatkan dalam 4 bulan adalah Rp 80.000.000 untuk profesi tukang bangunan. Sedangkan menoreh karet hanya menghasilkan $\mathrm{Rp} 800.000$ dalam 4 bulan. Bagi tukang bangunan yang memiliki perkebunan karet keuntungan lebih akan dirasakan. Karena kebun yang dimiliki dapat ditoreh oleh orang lain dengan pembagian 1:2.

Ramainya pembangunan rumah baru di Kampung Sarakaman Tengah dan Kampung Sarakaman Maju Mandiri ternyata tidak menambah permintaan kayu bagi penyenso atau jasa tukang bangunan masyarakat Kampung Tengah 
asli. Masyarakat dari Kampung Pasar dan Sungai Dungun membangun rumah baru membeli kayu dari penyenso asal Kampung Pasar dan Sungai Dungun. Seperti yang dialami oleh Pak MNI dan dua adiknya yang kini sudah tidak rutin mencari kayu.

\begin{abstract}
"Sakit pak sekarang, kami sudah kada rutin cari kayu buat dijual. Kayu sudah susah dicari. Apalagi sekarang banyak masyarakat Sungai Bali cari kayu di Desa Sarakaman di lahan SILO. Dulu kami sering jual kayu untuk perusahaan untuk pembangunan mes atau kantor. Tapisekarang perusahaan sudah buat bangunan permanen kada butuh kayu lagi. Kayu sekarang juga kada boleh dijual ke kota. Sawat sampai tahun 2000 kami masih boleh jual kayu ke kota. Sekarang kita cari kayu buat dijual kemana lagi?. Rumah-rumah baru juga beli kayu ke penyenso Kampung Pasar dan Sungai Dungun. Makanya sekarang ini, kita cari kayu ya buat rumah sendiri aja, sama buat kayu bakar." (Pak MNI)
\end{abstract}

Saat ini masyarakat dapat mencari kayu di lahan PT SILO untuk kebutuhan dapur dan bangunan rumah. Kini masyarakat sudah jarang menyenso kayu untuk dijual ke perusahaan. Sebelumnya perusahaan membutuhkan kayukayu untuk pembangunan mes dan kantor. Pembangunan dengan kayu dilakukan untuk mendukung aktivitas penambangan yang berpindah-pindah. Ketika kandungan bijih besi telah habis maka bangunan-bangunan dari kayu dapat dibongkar dan dipindahkan. Namun saat ini perusahaan sudah mulai membangun bangunan permanen menggunakan batu dan pasir.

Pada saat perusahaan membutuhkan banyak kayu. Penyenso mendapatkan banyak penghasilan dari permintaan kayu yang tinggi. Penebangan pohon dilakukan di wilayah PT SILO yang belum tergarap penambangan. Namun aktivitas masyarakat ini sering ditekan oleh pihak kepolisian dan kehutanan karena aktivitas penebangan liar. Padahal aktivitas penebangan pohon dilakukan di wilayah perusahaan dan atas permintaan perusahaan. Untuk memperlancar aktivitas penebangan masyarakat mengeluarkan biaya sebesar Rp 50.000 untuk setiap chainsaw per bulan melalui kepala desa untuk diserahkan kepada kepolisian Kotabaru. Menurut seorang penyenso hal tersebut tidak begitu merugikan karena dengan begitu aktivitas pencarian kayu menjadi lebih leluasa.

Sejalan dengan semakin sepinya permintaan atas kayu. Sebagian penyenso dari Kampung Sarakaman Tengah melakukan perubahan mata pencaharian menjadi nelayan di Sungai Dungun. Mereka telah memiliki perahu dan jaring setelah mendapatkan uang pembebasan kebun karet. Seperti yang dilakukan oleh Pak UJ yang beralih menjadi nelayan setelah pekerjaan menyenso tidak menghasilkan seperti dahulu. Iya mencari udang di Selat Sebuku dengan menggunakan rengge. Sekali melaut minimal mendapatkan uang Rp 80.000. Uang tersebut didapatkan setelah menjual udang ke pengumpul yang tinggal di Sungai Dungun dan dikurangi modal seperti bensin untuk motor dan perahunya. Dalam sekali melaut nelayan membutuhkan 10 liter bensin untuk mencapai Selat Sebuku. Artinya nelayan harus mengeluarkan uang sebanyak $\mathrm{Rp} 80.000$ untuk melaut. Ketika jaring yang dimiliki rusak, jaring tersebut dibawa ke rumah untuk diperbaiki. Akibatnya usaha mencari udang tidak dapat dilakukan. Maka biasanya mereka pergi memancing ikan dilaut untuk makan sehari-hari.
"Kaya sekarang mase, sidin pergi mancing ikan ke laut. Sidin kada bisa cari udang. Itu renggenya masih diperbaiki.”(Ibu FJR)

Pulau Sebuku dan Desa Sarakaman khususnya pada awalnya merupakan daerah penghasil lada di Kalimantan Selatan. Pada zaman penjajahan Belanda masyarakat banyak membuka hutan dan berkebun lada. Di Desa Sarakaman menaman lada dilakukan oleh generasi pertama sampai generasi kedua. Lada yang dihasilkan dari tanah Pulau Sebuku ini memiliki kualitas yang lebih baik dibandingka dengan lada hasil tanam di Pulau Laut. Seperti yang diungkapkan oleh salah seorang ketua RT di Desa Sarakaman.

"Lada dari Pulau Sebuku ini terkenal bagus kualitasnya mase. Bijinya itu kecil-kecil tapi keras dan lebih pedas. Dibandingkan lada dari Pulau Laut besar-besar tapi tidak keras seperti lada di sini. Mungkin karena tanah di sini besi semua mase." (Pak SYD)

Generasi pertama Desa Sarakaman berasal dari daerah Rantau yang melakukan pelarian diri akibat penjajahan Belanda. Kai-kai masyarakat Desa Sarakaman melakukan pembukaan hutan untuk berladang. Lada adalah komoditas yang banyak ditanam oleh masyarakat Rantau. Sampai akhirnya lada mulai ditanam di Pulau Sebuku. Pada masa penjajahan Belanda lada menjadi komoditas utama yang laku dijual di Eropa. Hal ini dapat terlihat bagaimana Belanda mendirikan NIGIEO (Netherlands Indies Government Import-Export Organization) utnuk menangani ekspor Lada. Pada April 1947 sampai April 1948 sekitar 543 ton lada dengan nilai 2.003.384,29 gulden dibeli oleh NIGIEO dari para petani. (Heidhuis 1992 dalam Erwiza 2009).

Seiring dengan bertambahnya masyarakat yang menanam lada, mengakibatkan harga jual lada semakin menurun. Pada tahun 2004, lada mencapai harga jual terendah yaitu Rp 35.000 per $\mathrm{kg}$. Jatuhnya harga lada disebabkan stok yang melimpah yang dimiliki petani maupun pengumpul. Di waktu yang bersamaan perusahaan tambang bijih besi sudah memulai eksploitasinya di daerah Sungai Bali. Menurut salah seorang pengumpul lada lada sudah mulai ditinggalkan masyarakat semenjak tanamanan lada gagal berbuah akibat debu-debu pertambangan. Banyak tanaman lada masyarakat mati dan tidak dilanjutkan penanaman kembali. Perkebunan lada mulai tergantikan dengan tanaman karet. Beralihnya masyarakat Desa Sarakaman dari berkebun lada menjadi karet disebabkan oleh beberapa hal. Pertama, berkebun lada dianggap tidak menguntungkan lagi semenjak harga jual yang menurun. Kedua, getah karet muncul sebagai komoditas yang bernilai tinggi. Ketiga, masa panen lada yang singkat dibandingkan karet. Keempat, perawatan yang lebih intensif dalam berkebun lada dibandingkan berkebun karet. Sehingga, saat berakhirnya masa hidup tanaman lada. Masyarakat mulai menggantikannya dengan tanaman karet. Tanaman karet yang ditanaman di Desa Sarakaman adalah jenis kampung yang ditanam mulai dari biji. Karet jenis kampung ini dianggap memiliki masa hidup yang lama. Hingga saat ini tanaman karet yang berada di Desa Sarakaman sudah berusia 60 tahun. Pada awalnya tanaman karet sangat menguntungkan bagi masyarakat Sarakaman harga jual karet sempat mencapai puluhan ribu per $\mathrm{kg}$ getah karet. Namun harga jual getah karet terus menurun sampai harga Rp 5.000 per kg getah kering dan Rp 2.000 per kg getah basah. Padahal sebelumnya harga karet kering sempat mencapai Rp 12.000 per kg getah karet kering dan 


\section{Rp 4.000 per kg getah basah}

Kepemilikan kebun karet di Desa Sarakaman oleh masyarakat semakin menurun saat masuknya perusahaan. KP perusahaan yang didapatkan dari Bupati mencakup kebun-kebun karet masyarakat. Seperti masyarakat di Pondok Bai banyak menjual kebun karet kepada perusahaan seharga Rp 500 sampai Rp 1.500 per meter. Masyarakat Pondok Bai menjual kebun karet pemberian warisan orang tuanya. Mereka memilih menjual kebun warisan karena sudah lama tidak tergarap. Namun ada pula yang menjual sebagian kebun karet aktif karena sudah tidak menguntungkan lagi. Selanjutnya mereka menggantikan sisa-sisa lahan yang dimiliki untuk ditanam lada. Hal tersebut mereka lakukan karena lada saat penelitian berlangsung memiliki harga jual yang sangat tinggi yaitu $\mathrm{Rp} 110.000$ per kg. Masyarakat senantiasa mengikuti atau melakukan perubahan strategi nafkah sesuai keuntungan yang akan didapatkan. Masyarakat akan meninggalkan pekerjaan yang dianggap merugikan.

Bagi masyarakat yang tidak memiliki lahan garapan, mereka bekerja di kebun-kebun karet orang lain. Sebagian besar kaum perempuan di Kampung Sarakaman Tengah menjadi penoreh karet di kebun orang lain. Pekerjaan dilakukan oleh kaum perempuan untuk menambah pemasukan keluarga. Seperti yang dilakukan Ibu FJR yang menoreh karet dari pukul 06.00 sampai 11.00 WITA. Dalam dua hari ia dapat menjual karet sebanyak $10 \mathrm{~kg}$ kepada pengumpul. Harga per kg getah karet adalah Rp 5.000. Sehingga uang yang didapat adalah $\mathrm{Rp} 50.000$ per 2 hari dan harus diberikan 1 bagian kepada pemilik kebun karet. Maka uang bersih yang didapatkan penoreh seperti Ibu FJR ini adalah Rp 30.000 dalam 2 hari. Lokasi kebun karet yang biasa ditoreh oleh Ibu FJR berada jauh di belakang kampung Sarakaman Maju Mandiri. Untuk mengakses kebun karet ia harus menggunakan sepeda motor sampai ke dalam hutan.

"Saya baru sebulan mas noreh. Sebelumnya saya di rumah aja. Tapi karena pendapatan suami ngga cukup. Jadi saya noreh, tapi uangnya kada banyak 30 ribu aja mas 2 hari. Kalau suami sekarang sudah jarang nyenso. Kadeda lagi yang beli kayu. Kayu sekarang juga susah dicari di hutan. Makanya sekarang suami melaut aja, mancing. Renggenya masih diperbaiki. Ya hasil mincing buat makan aja." (Ibu TJR)

Menurut Tulak (2009), bahwa orang miskin cenderung berada dalam tingkat kerentanan hidup yang tinggi. Dengan segala macam keterbatasannya tersebut, orang miskin pasti akan melakukan berbagai cara dengan merubah strategi nafkah untuk bertahan hidup.

\section{Lingkungan dan Masyarakat Miskin di Desa Sarakaman}

Masuk dan berkembangnya industri pertambangan di Desa Sarakaman mengakibatkan berkurangnya akses masyarakat terhadap sumber daya alam seperti hasil tangkapan nelayan maupun lahan garapan masyarakat. Seperti yang dialami oleh kelompok nelayan yang masih tertinggal di Kampung Sungai Dungun merasakan hasil tangkapan ikan yang menurun semenjak aktivitas penambangan dilakukan di Desa Sarakaman. Hal tersebut diakibatkan oleh berubahnya ekosistem sungai dan aliran limbah perusahaan ke sungai dan laut. Seperti yang diungkapkan oleh salah satu nelayan Kampung Sungai Dungun bahwa hasil tangkap ikan nelayan jauh berkurang setelah masuknya perusahaan di
Desa Sarakaman.

“Hasil tangkap kita sekarang berkurang 40 per sen. Kaya tadi saya cuman dapat 7 kilo kali 27 ribu. Sedangkan untuk modal sekali melaut saya keluar 210 ribu. Saya harus ngutang ke pengumpul, sekarang sekitar 17 juta. Ya mungkin sampai mati utang saya tu. Hasil lautnya itu mase sakit. Ikan di pinggir bakau aja susah. Padahal bakau kan tempat hidupnya ikan." (Pak SHR)

Nelayan kecil seperti Pak SHR menghadapi kehidupan yang semakin sulit semenjak pengerukan batubara di Desa Sarakaman. Hasil tangkap ikan menurun drastis hingga 40 per sen. Sementara itu biaya melaut untuk tetap bertahan hidup semakin tinggi. Hal ini yang mendorong nelayan terus berhutang kepada pengumpul. Nelayan kecil biasa berhutang untuk perawatan jaring, perahu dan bahan bakar. Tanpa berhutang mereka tidak akan dapat melaut untuk menghidupi keluarga. Kehidupan nelayan di Sungai Dungun sangat bergantung pada kondisi ekosistem laut yang mempengaruhi hasil tangkapnya. Mereka tidak memiliki kemampuan untuk menguasai teknologi. Saat ini jaring yang mereka gunakan adalah jaring untuk udang, ikan besar dan ikan bawal. Sementara daya jangkau nelayan terbatas di Selat Sebuku.

Di Desa Sarakaman Tengah, masyarakat tidak dapat lagi mempergunakan air sungai untuk air minum. Semenjak masuk dan berkembangnya industri pertambangan biji besi di daerah hulu, air sungai berubah menjadi keruh kecoklatan. Saat ini masyarakat menggunakan sumur bor untuk air minum dimana mesin air diberikan oleh perusahaan. Satu unit mesin bor digunakan untuk 5-10 rumah tangga. Tercemarnya aliran sungai di Desa Sarakaman juga mempengaruhi sumber penghidupan masyarakat yang biasa memancing dan menombak ikan. Ikan-ikan hasil tangkapan dari sungai biasa dikonsumsi untuk makan sehari-hari. Namun kini masyarakat harus membeli ikan untuk dapat mengkonsumsinya. Menurut ketua RT di Kampung Sarakaman Tengah sungai merupakan salah satu sumber penghidupan masyarakat selain perkebunan. Saat hujan deras maka sungai berubah menjadi keruh dan butuh waktu lama untuk kembali jernih. Meski demikian masyarakat tidak menggunakan air sungai untuk konsumsi. Mereka meyakini jernih belum lah tentu dapat diminum. Masyarakat meyakini bahwa air sungai telah tercemar oleh zat kimia berbahaya dari perusahaan.

Masyarakat Desa Sarakaman terus menghadapi tekanan dari berkurangnya daya dukung lingkungan kerusakan hutan dan sungai akibat perluasan aktivitas tambang oleh dua perusahaan mendesak masyarakat untuk berusaha di luar dari kebiasaan untuk dapat bertahan hidup. Seperti yang dialami oleh Pak SRN, ia melakukan penambangan pasir di daerah sungai untuk dijual. Hasil pengerukan pasir dijual seharga Rp 2.000 per karung. Pasir dibeli oleh masyarakat lain untuk membangun rumah. Pekerjaan ini menjadi pilihan terakhir ketika akses bekerja di perusahaan telah tertutup, berkebun dan melaut semakin sulit. Berikut adalah penjelasan Pak SRN.

"Saya kadang menggali pasir di sungai untuk dijual. Saya baru aja kerja seperti ini. Mau berkebun hasilnya kada seberapa, kebun karet peninggalan orang tua kada seberapa luasnya. Sebelumnya saya pernah menyenso, tapi sekarang kada bisa lagi. Kayunya 
sudah kada ada, sekarang juga kita dilarang ngambil kayu sama kehutanan." (Pak SRN)

Berbeda dengan Pak SRN yang mengaku bahwa ia telah meninggalkan pekerjaan menyenso kayu. Di Desa Sarakaman masih terdapat penyenso kayu. Pekerjaan ini dilakukan ketika ada pesanan untuk pembangunan rumah baru. Biasanya dalam satu hari penyenso menebang 2 pohon untuk menghasilkan 1 kubik kayu. Mereka memulai aktivitas dari pukul 09.00 sampai 16.00 WITA. Menurut salah seorang penyenso aktivitas penebangan pohon kini dilarang oleh aparat kehutanan kecuali kayu hasil tebangan dimanfaatkan untuk kebutuhan masyarakat Pulau Sebuku. Dibandingkan dahulu kayu-kayu dari Pulau Sebuku bebas dijual ke kota. Pada saat itu kayu yang didapatkan penyenso dijual kepada pengumpul di Desa Sarakaman dan selanjutnya dibawa ke Kotabaru. Namun setelah larangan dikeluarkan oleh kehutanan, pengumpul kayu sudah tidak ada lagi di Pulau Sebuku. Kini penyenso dapat langsung memperjual belikan ke pembeli dalam lingkup Pulau Sebuku. Meski demikian hasil kayu yang didapatkan penyenso semakin terbatas mengingat persediaan kayu di Pulau Sebuku sudah jauh berkurang semenjak masuk dan berkembangnya industri pertambangan. Kayu ulin yang merupakan kayu unggulan di Pulau Sebuku sudah sulit dicari. Saat ini masyarakat hanya dapat mencari kayu-kayu jenis MC dengan kualitas dan harga yang rendah. Penyenso biasa mencari kayu jenis ini di wilayah KP perusahaan yang telah dibebaskan dan juga di lahan perkebunan masyarakat. Penebangan di wilayah perusahaan tidak dilarang oleh pihak perusahaan. Mengingat kawasan tersebut selanjutnya akan dikeruk untuk ditambang biji besinya.

Setelah perusahaan menambang bijih besi untuk kualitas pertama. Bekas galian tersebut ditanami sengon yang berasal dari bibit masyarakat. Bibit sengon dibeli oleh perusahaan dari masyarakat seharga $\mathrm{Rp} 5000$ per bibit dan ditanam oleh karyawan perusahaan. Suatu saat bekas galian tersebut akan kembali digali untuk dikeruk bijih besi kualitas kedua. Ketika lokasi tersebut akan ditambang kembali pohon-pohon sengon belum dapat dipastikan apakah dapat dimanfaatkan oleh masyarakat atau tidak. Jika demikian harapan masyarakat untuk dapat bertahan hidup dengan mencari kayu semakin kecil. Mengingat persediaan kayu di Desa Sarakaman telah jauh berkurang.

Persediaan kayu di Desa Sarakaman semakin berkurang. Terutama ketersediaan kayu ulin. Kayu ulin adalah kayu yang biasa digunakan untuk pembangunan rumah terutama untuk dasar rumah masyarakat. Hal ini mengakibatkan masyarakat mencari sisa-sisa tebangan pohon ulin di hutan. Kayu-kayu ulin yang tersisa masih dapat dimanfaatkan untuk tongkat dan alas rumah masyarakat. Seperti yang dilakukan Pak MMG, ia mencari sisa-sisa kayu ulin di lahan garapan orang lain. Menurutnya apa yang ia lakukan adalah hal yang tidak dilarang karena memanfaatkan sisasisa kayu ulin yang berserakan. Selain itu selama sisa-sisa ulin tidak dijual bukan lah hal yang merugikan bagi pemilik kebun. Menurut Redclift (1984), bahwa kemiskinan yang diakibatkan oleh tekanan struktur pada masyarakat membawa pada kerusakan lingkungan akibat aktivitas ekonomi yang dilakukan.

\section{SIMPULAN}

Berdasarkan penelitian ini dihasilkan kesimpulan, yaitu (1) perizinan industri pertambangan dikeluarkan oleh pemerintah daerah tanpa melalui kesepakatan masyarakat lokal, (2) ganti rugi dalam pembebasan lahan dan tempat tinggal masyarakat yang dilakukan oleh perusahaan pertambangan terbilang besar, namun tidak sebanding dengan keberlanjutan sosial ekonomi masyarakat, (3) masuk dan berkembangnya perusahaan pertambangan mengurangi aksesibilitas masyarakat atas sumber daya agrarian, (3) di tengah keterbatasan akses sumber daya agraria, masyarakat terus melakukan strategi nafkah untuk bertahan hidup dan (4) rusaknya lingkungan akibat masuk dan berkembangnya industri pertambangan mempersulit aktivitas ekonomi dan pemenuhan kebutuhan hidup masyarakat.

\section{SARAN}

1. Perlunya merevisi Peraturan Menteri Kelautan dan Perikanan RI Nomor 20/MEN/2008 tentang pemanfaatan pulau-pulau kecil dan perairan di sekitarnya, pada pasal 3 ayat 3 dengan menambahankan pertimbangan sosial budaya masyarakat lokal di pulau kecil.

2. Perlunya mempertimbangkan keberlanjutan sosial ekonomi masyarakat miskin yang terkena pembebasan tempat tinggal, terutama nelayan yang sangat bergantung pada sungai

3. Perlunya penelitian lanjutan dengan menggunakan metode survei untuk mengetahui mobilisasi kelas masyarakat.

\section{DAFTAR PUSTAKA}

[SAINS] Sajogyo Institut, [STPN] Sekolah Tinggi Pertanahan Nasional. 2009. Memahami dan Menemukan Jalan Keluar dari Problem Agraria dan Krisis Sosial Ekologi. Yogyakarta (ID): STPN.

Denzin NK, Lincoln YS. 2009. Handbook of Qualitative Research. Dariyatno, Fata BS, Abi, Rinaldi J, penerjemah; Qudsy SZ, editor. Yogyakarta (ID): Pustaka Pelajar. Terjemahan dari: Handbook of Qualitative Research. Ed ke-1.

Erman, E. 2005. Membaranya Batubara, Konflik Kelas dan Etnik. Depok (ID): Desentra.

Erman, E. 2007. Rethinking Legal and Illegal Economy: A Case Study of Tin Mining in Bangka Island. [tidak diketahui]

Erman, E. 2009. Menguak Sejarah Timah Bangka Belitung. Yogyakarta (ID): Ombak

O'Faircheallaigh C. 2013. Extractive Industries and Indigenous People: A Changing Dynamic?. Journal of Rural Studies 30 (2013): 20-30. Elsevier Science Ltd.

Paige J. 1975. Agrarian Revolution. New York (US): The Free Press

Peluso NL. 2006. Hutan Kaya Rakyat Melarat, Penguasaan Sumberdaya dan Perlawanan di Jawa. Simatupang L, penerjemah; Fauzi N, editor. Jakarta (ID): Konphalindo. Terjemahan dari: Rich Forest, Poor People: Resource Control and Resistance in Java. 
Ed ke-1.

Pincus J. 1996. Class Power and Agrarian Change. United State (US): ST. Martin's Press, Inc.

Puspitasari D. 2010. Pengembangan Kebijakan Agraria. Yogyakarta: STPN Press dan Sains.

Redclift, Michael. 1984. Development and the Environmental Crisis: Red or Green Alternatives?. London dan New York: Methuen

Scott S. 2012. Revisiting Rural Places: Pathways to Poverty and Prosperity in Southeast. Rigg J, Vandergeest P, editor. Singapore: NUS Press.

Shohibuddin et al. 2010. Memahami Dimensi Kemiskinan Masyarakat Adat. Jakarta (ID): AMAN ICCO. 